\title{
Translating Figurative Proverbs from Two Syrian Novels:Muftaraq al-MațarbyYūsuf al- Maḥmūd and Anājīl al-Xarāb by NaufalNayouf
}

\author{
Huwaida Issa \\ Department of Arabic, Islamic and Middle Eastern Studies \\ University of Leeds, United Kingdom
}

\begin{abstract}
This paper studies the possibilities of translating a few figurative proverbs, mainly metaphorical, in the two Syrian novels Muftaraq al-MațarbyYūsuf al-Maḥmūd and Anājīl al-Xarāb by NaufalNayouf. It also showcases how to translate proverbs with phonic features such as alliteration, assonance and rhyme. This is done by taking examples from the aforementioned novels and examining these formal features before and after translating the selected proverbs. This research also reviews a few scholarly approaches to the translation of culture-bound items, metaphor and proverbs. It then focuses on implementing Toury's view on translating metaphor and shows how many proverbs have preserved metaphor, alliteration, assonance and rhyme in the target language (TL), and how many proverbs have lost these stylistic devices in the TL.
\end{abstract}

Key words: culture, metaphor, phonic features, proverbs, translation.

Cite as: Issa, H. (2017). Translating Figurative Proverbs from Two Syrian Novels:Muftaraq alMațarbyYūsuf al-Mạ̣mūd and Anājīl al-Xarāb by NaufalNayouf. Arab World English Journal for Translation \& Literary Studies, 1(2). DOI:http://dx.doi.org/10.24093/awejtls/vol1no2.6 
AWEJ for Translation \& Literary Studies volume, 1 Number 2, May 2017

Translating Figurative Proverbs from Two Syrian Novels

Issa

\section{Introduction}

This paper considers the translation of a fewSyrian proverbs. These proverbs are taken from the two Syrian novels, Muftaraq al-MațarbyYusuf al-MaḥmūdandAnājīl al-Xarāb by Naufal Nayouf. These novels have never been translated before. In this paper, the researcher has chosen to use the terms external and internal features of proverbs. This is based on Seiler's approach and use of the aforementioned terms. According to Seiler(1922, p.4 as cited in Norrick, 1985, p. 46)), internal features of proverbs refer to the figurative aspects of proverbs such as metonymy, metaphor, personification, etc; while external features of proverbs refer to rhyme, alliteration, assonance, etc. The researcher then presentsa number of proverbs which exhibit the external formal features of alliteration, assonance and rhyme; and in addition chooses a number of proverbs with the internal formal feature of metaphor. The effect of translation on both types of proverbs is then considered. The researcher also uses seven proverbs from both novels and attempts to show the different possibilities of translating these figurative proverbs. Then shediscusses them in the light of Toury's criteria for translating metaphor (section 3.1). This study also covers eight examples of proverbs with alliteration, assonance and rhyme, and explores the question whether the phonic features in the source text (ST) have been preserved in the target text (TT) (sections 7.1, 7.2 and 7.2.1).

\section{Culture and Translation}

Many scholars have researched how to translate texts that are impregnated with culture- specific words. Larson (1984, pp. 436-7), for example, keeps both cultures in mind, approaching cultural translation in terms of the way the translator helps the receptor audience understand the content and intent of the source document. Accordingto Newmark (1998, p.95), when the translator encounters a text which heavily includes cultural items, it is worth keeping in mind the cultures of both the ST and the TT, and finding a proper technique to convey the message of the ST meaning. This means that translators should act as the facilitator between the two cultures, as it is not only with two languages that they are dealing. Therefore, Newmark argues that the literal translation of culturally-specific words within the text is not the best option for the translator. In order to avoid inaccuracy, the translation "may include an appropriate descriptive-functional equivalent" (Newmark1998, p. 95).

Scholars in translation studies have used different terms to express their understanding about the wordswhich exist in a specific source language and culture but do not have an equivalent in the target language culture. For instance, according to Newmark(1998, p. 96), a "cultural word" means that the receiver of the translated text cannot understand this word if it is translated literally.Baker argues that a cultural concept may be "abstract or concrete; it may relate to a religious belief, a social custom, or even a type of food." Baker refers to these elements as "culture-specific" (Baker 1992, p. 21). Interestingly, Nord (1997, p. 34), uses the abbreviated form "cultureme" for what Baker calls a "culture-specific "feature.Nord defines cultureme as "a social phenomenon of a culture $\mathrm{X}$ that is regarded as relevant by the members of this culture and, when compared with a corresponding social phenomenon in a culture Y, is found to be specific to culture X"(Nord 1997, p. 34).

\section{Strategies for translating culturally-bound phrases.}

There are multiple ways to translate a text from one culture to another. These translation strategies can be biased either towards the source language and culture or towards the target 
AWEJ for Translation \& Literary Studies volume, 1 Number 2, May 2017

Translating Figurative Proverbs from Two Syrian Novels

Issa

language and culture. A foreignized text will be the outcome of a translation process that adopts the first strategy; while a domesticated text will result from the second strategy. Foreignizinga text may involve introducing new words to the target language. This may be produced through literal translation. However,(Ghazala, 2008, p.12 as cited in Balfakeeh, 2009, p. 10), argues that when the translator takes the route of domesticating, then he/she is not committed to translating every single word or phrase.

\subsection{Culture/language translating strategies}

There are different strategies for the translator of a culturally-specific text to opt for in order to convey the message received by the ST reader to the TT reader. The first strategy is literal translation. This will be successful if the TT reader is acquainted with the cultural implications of the translated text as a whole. The strategy of literal translation of culturallybound expressions can be used when the translator knows that the TT reader will be familiar with the cultural background reflected in the ST (Sanchez, 2007, p.129). The second strategy is when the translator intervenes to clear up ambiguities in the ST for benefit of the TT reader. The third strategy is paraphrasing, which is one of the pro-TL strategies (Ghazala, 2008, p. 12 as cited in Balfakeeh, 2009, p. 10). The fourth strategy isusing a TL equivalent, which is a sub-type of domestication (ibid). The fifth strategy is borrowing. Finally, there is the deletion strategy, where the translator may have recourse to deletingcertain expressions from the ST when they are considered a taboo in the TL.

The latter strategy of deletion has been discussed by Dickins (2012, p. 47), pinpointing the fact that it is sometimes inappropriate to translate certain words/phrases from the SL to the TL. Therefore, it is wise to link "omission as a cultural translation procedure with problem avoidance: by not attempting to find any equivalent for the ST word or phrase, the problem of what is an appropriate equivalence might be avoided!" (ibid).In some cases a combination of more than one strategy is needed to convey the meaning because "in many cases the social environment which underlies the SL will require an adaptation, an explanation or a paraphrasing rather than, strictly speaking, a translation" (Sanchez, 2007, p. 129). This point is reiterated by Catford(1965, p. 73 as cited in Munday, 2012, p. 93), in his view of translation shifts as "departures from formal correspondence in the process of going from the SL to the TL".

\section{Definition of proverbs}

Perhaps the most detailed definition of a proverb is provided by Norrick (1985, p.31), who defines proverbs as "self-contained, pithy, traditional expressions with didactic content and fixed, poetic form". Meider ( 2008, p.11) highlights that the use of figures of speech, mainly metaphor, is a key characteristic in most proverbs: "A proverb is a short, generally known sentence of the folk which contains wisdom, truth, morals and traditional view in a metaphorical, fixed and memorisable form and which is handed down from generation to generation". Shirley Arora (1984, p.13), stresses the importance of the stylistic characteristics of proverbs, arguing that "proverbiality" is what gives a sentence the possibility of being a proverb. This means its richness in stylistic devices. This includes structural markers such as parallelism or poetic markers such as rhyme or the use of figurative language such as metaphor.

According to Longman III (2002, p. 38), “A proverb wastes no words. Proverbs are written in poetic form, and poetry in general is compact language".Similarly, Lawrence Boadi 
AWEJ for Translation \& Literary Studies volume, 1 Number 2, May 2017

Translating Figurative Proverbs from Two Syrian Novels

Issa

focuses on the stylistic effect of proverbs: "Proverbs are primarily manners of elegant speech and not simple kernels of wisdom" (Adeeko, 1998, p. 31). The same idea of the stylistic properties of proverbs is also mentioned by Jesenšek (2014, p.138), who argues: "If we consider the terminology of the classical rhetoric, we can state that proverbs account to theOrnatus(ornament) of the speech, as they use their properties as rhetorical figures". In this paper, the focus will be on the proverbs which have the following figurative aspects:metaphor, alliteration, assonance and rhyme.

\subsection{General principles for translating proverbs}

Many scholars have studied the different possible methods of translating proverbs. According to Baker (1992, p. 65), to translate idioms or proverbs, the translator may opt for one of four strategies. The first strategy is to choose from the TL an idiom which corresponds with the form and the meaning of the idiom in the SL. The second strategy is to match from the TL an idiom which has the same meaning but not the same formal structure of the SL idiom. The third strategy for the translator is to apply paraphrasing, while the fourth strategy is to use omission.Vinay and Darbelnet(1995, pp.38-9; 2004, p. 134, as cited in Munday, 2012, p. 89) argue that in some linguistic cases such as proverbs and idioms, the sense/meaning may be a priority for the translator. This means that the translator of such phraseological units may not necessarily conform to the "stylistic or structural" components of the SL. This is what they (ibid) refer to as equivalence.

According to Nida(1985, ascited in Al-Timen, 2015, p. 14016),"proverbs are special metaphoric expressions and the translator should know the proverbial concepts in both source language SL/target language TL, which means to bear in mind their similarities and differences". This means that a certain proverb may exist in SL and TL, but with different meanings. It may also mean that a SL proverb may have a correspondent proverb in the TL, with a similar formal structure. According to Bell (1991, p. 6 as cited in Al-Timen 2015, p. 14019), the process of translation "by definition, [may demand] to alert the forms". This explains the transformation in the formal structure of some of the translated proverbs.

Certain phrases from the SL cannot have the same elements in the TL; but may have a different counterpart. In this case, it is wise to apply the cultural transplantation strategy, which is discussed byDickins (2012, p.58),who gives the following example: if the translator encounters the phrase قيسوليلىin the Arabic SL text, it is worth using the cultural transplantation "Romeo and Juliet" in the English TL text. This point is repeated by Al-Timen, (2015, p. 14024), who has built her argument on Catford's (1965) view of equivalence/substitution. Al-Timen, (2015, p. 14024) gives an example, "As wise as an owl” and its translation: "حكيم كلقمان", which resonates more with Dickins, Hervey and Higgins' view of cultural transplantations: "whose extreme forms are hardly translations at all but more like adaptations- the wholesale transplanting of the entire setting of the ST, resulting in the entire text being rewritten in an indigenous target culture setting" (2002, Need P.N.). Al-Timen,(2015) proceeds to explain the cultural background of the "owl" in both the SL and TL.In English the "owl" has a positive connotation and it is associated with wisdom as well; in the Arabic TL, however, "owl" has a negative connotation, and the best substitute for it is "لقمان" (Solomon), who is a figure known for representing wisdom. 
AWEJ for Translation \& Literary Studies volume, 1 Number 2, May 2017

Translating Figurative Proverbs from Two Syrian Novels

Issa

\section{Definition of metaphor}

Metaphor is an important characteristic of the majority of proverbs. According to Richards (1965, as cited in Bock and Brewer, (1980):

Metaphors are composed of two principal terms, the topic and vehicle, and the relationship between them, the ground. The topic is usually the subject of the metaphorical sentence, while the vehicle is the term being used metaphorically. The ground is created by the points or relations of similarity between the two.( p.60)

Another view about metaphor is put forward by Ricour(as cited inSandoval, 2006, p.7), who sees that in a sentence, the tension between the literal meaning and the metaphorical meaning is what creates metaphor: "Yet the tension in a metaphorical utterance is really not something that occurs between two terms in the utterance, but rather between two opposed interpretations of the utterance". For example, when looking at the following proverb: مليحة هذه العلّيقة لهذا الحمار (المحمود،

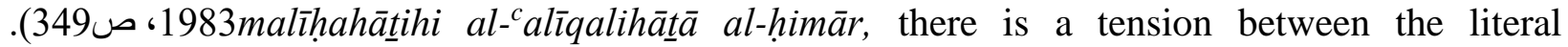
meaning (This nosebag is good for this donkey) and the metaphorical meaning in the context of the novel (to find a woman for Musallim to marry). In the novel, it looks like Musallim is not an obedient teenager and his mother is thinking of marrying him to a woman similar to her son Musallim in nature, hoping that Musallim will change and become a better person then. In this proverb the image of the donkey corresponds with the stubborn nature of Musallim. So, as a donkey needs fodder when it is hungry or angry; similarly, Musallim needs a woman to tame

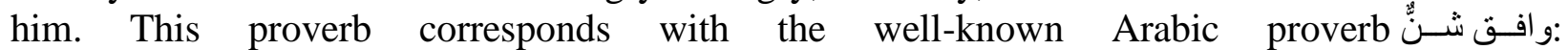

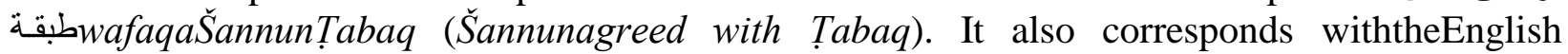
proverb: Birds of a feather flock together.

\subsection{General principles of translating metaphors}

The topic of how to translate metaphors from SL to TL has interested many researchers.AlHasnawi(2007, as cited in Al Salem, 2014, p.108),suggests two models for translating metaphor: 'similar mapping conditions' and 'different mapping conditions', building his argument on the fact that translating metaphor from Arabic into English may be a slightly more difficult challenge since the two cultures are very distant from each other. Thus, the first model may not be the ideal one to adopt in most cases. However, the translator may find a similar metaphor in the TL, such as 'he fell in love' for the SL “(وقعفيالحب)" (Al-Hasnawi, 2007 as cited inAl Salem, 2014, p. 109). The other scenario in translating metaphor from the SL text to the TL reader is represented in the following example:“"يزيدالطينبّة".'If the translator translates it word for word, following the first model by Al-Hasnawi (2007), the outcome will not be the correct translation:"to make mud wetter". So, the second model will be the right option. This is achieved through following AlHasnawi's "different mapping conditions", and consequently finding an appropriate equivalence: "to add insult to injury" (ibid).

According to Vinay andDarbelnet(1995, pp. 39-40; 2004, pp. 134-6 as cited in Munday, 2012, p.89), adaptation is a very useful tool and may even be the only choice for the translator when dealing with/encountering specific metaphors. They (ibid), give the following example: "the cultural connotation of a reference to the game of cricket in an English text might be best translated into French by a reference to the Tour de France". They proceed to explain further that this modified metaphor may work only in this specific phrase/context. 
AWEJ for Translation \& Literary Studies volume, 1 Number 2, May 2017

Translating Figurative Proverbs from Two Syrian Novels

Issa

Toury(1995, pp.82-83), and also(as cited in Poucke\&Belikova, 2016, p. 350), it is clear that Toury (1995, p.82) states that translating metaphor could involve the "coupled pair" costituents of "replacing/replaced" metaphors. This is explained in unfolding six strategies for translating metaphor. The first strategy is when the translator succeeds in finding the same metaphor in the TL. The second strategy is when the translator exchanges the SL metaphor with a TL different metaphor. The third strategy is to sacrifice the SL metaphor and translate it using non-metaphor in the TL. This could be done through giving the overall meaning of the metaphor. This can be done through explaining the metaphor with more words. The fourth strategy is to totally drop the SL metaphor in the TL. In this case, omission is what describes this process. The fifth strategy is to substitute the non-metaphor in the SL with a metaphor in the TL. This means creating a metaphor in the TL.The sixth strategy is to create a metaphor in the TL in order to fill a gap in the SL. Here, the translator may find that it is necessary to add a metaphor in the TL (Toury, 1995, p. 83).

\section{Principles of translating metaphorical proverbs}

Translating proverbs has never been an easy or straightforward task. This is mainly related to the fact that they are mostly figurative. According to Dabaghi, PishbinandNicknasab(2010):

Translating proverbs, the translator should know linguistic and non-linguistic features of both languages. By linguistic features we mean those elements which are not conveyed only through words, what is important here is culture. Each proverb conveys specific meaning in a specific context of situation. Therefore, a proverb should be rendered with care to carry the same cultural conventions in the original proverb. It is not reasonable to translate a proverb while just looking at the first meaning of its words in a dictionary.(p. 813)

According to Al Salem (2014, p.82), the difficulty in comprehending idioms properly stems from the fact that they may heavily dependon the metaphorical dimension within them. For instance, كhen encountering the following proverb: كأنّه ضربو ا بعاصفة واحدة (المحمود، 1983)

.(258 Ka'annahumụuribū bi- ${ }^{c} \bar{a}$ șifawāhida(As if they were hit by one single storm), the translator can find a correspondent in English, though it may not have the same image of a storm. The equivalent would be: to kill two birds with one stone (http://dictionary.cambridge.org/dictionary/english/kill-two-birds-with-one-stone). However, in the Arabic version, there is a sense of calamity and grief. This can be deduced from the context; whereas the English equivalent, as a lexicalised proverb,may bear luck and skill or misfortune. This depends on the context in which this proverb is employed. This point is supported by the Meider (2008, p.13), "the meaning of proverbs is thus very much dependent on the contexts in which in which they appear".

According to Mollanazar(2001, p. 54 as cited in Dabaghi, PishbinandNicknasab, 2010, p. 813), proverbs with figures of speech in the SL may not have their figurative correspondence inthe TL. Therefore, there are two ways to handle this translation situation. The first strategy is: "Some similar proverbs can be found in the two languages with more or less similar form, vocabulary and meaning"; while the second strategy suggests"Many proverbs may be found in 
AWEJ for Translation \& Literary Studies volume, 1 Number 2, May 2017

Translating Figurative Proverbs from Two Syrian Novels

Issa

the two languages which have similar meanings and can be applied in the same contexts, but they have different form and vocabulary".

\section{Examples of proverbs with metaphor}

This section will present seven metaphorical proverbs, and the different possibilities of translating them. The first four examples are taken from the Syrian novelMuftaraqalMatarbyYusufal-Mahmūd;while the last three examples are taken from the other Syrian novelAnājīl al-Xarāb by NaufalNayouf.

\section{Example 1:}

الجمل لا يرى حردبته(المحمود، 1983، صabah

Al-jamallāyarāḥirdabbatahu

\section{Literal translation}

The camel does not see its hump.

The hump here is a metaphor for a deficiency in somebody's appearance or character or personality. In this proverb, the intended meaning is "just as the camel cannot see his hunched back, so AbūMahmūd cannot see the deficiency in his daughter's appearance (the ugliness of his daughter's hair)".

Here the literal translation of the proverb does not convey the precise meaning of the proverb to the EnglishTL reader. This is because of the TL reader not being familiar with the SL culture and the associations of the culturally-bound item حردبته hirdabbatahu (hump), though this metaphor is lexicalized in some of the English dictionaries, but with a totally different meaning, namely "difficulty". Anotherway of translating this proverb is by paraphrasing it as follows:

"People do not see/realize their own deficiencies". In this translation, the paraphrasing technique has been used. However, it can be seen that the metaphor in the ST has not been kept in the TT. So, if we consider it in Toury'sterms of translating metaphor, the strategy that has been applied here is: metaphor in SL/no metaphor in TL.

\section{Example 2:}

$$
\begin{aligned}
& \text { ST } \\
& \text { عديم ووقع بسلة تين (المحمود، 1983، ص4alitina } \\
& \text { cadìmwa-waqac bi-sallittīn }
\end{aligned}
$$

\section{Literal translation}

A destitute and has newly got a basket of figs/ Empty-handed and in a basket of figs has landed. TL

Upstart or the most commonly used one (nouveau riche), which is a French loan expression. Another translation: A destitute who has newly become rich.

Here there is a metaphor based on the destitute person who has become full after having been hungry. Here the metaphor is "a basket of figs". If we adopt the following translation: "Empty- handed and in a basket of figs has landed", it will keep the metaphor but not convey the meaning to the TL reader. If we choose this translation: "Upstart (nouveau riche)", then there is a lexicalised non-metaphoric equivalent to the metaphorical proverb: "A destitute, and has newly 
AWEJ for Translation \& Literary Studies volume, 1 Number 2, May 2017

Translating Figurative Proverbs from Two Syrian Novels

Issa

got a basket of figs".InToury'sterms of translating metaphor, the strategy that has been applied here is: metaphor in SL/ no metaphor in TL.

\section{Example 3:}

$$
\begin{aligned}
& \text { من كبّر الحجر ماضرب (المحمود } 1983 \text { ص37araba } \\
& \text { Man kabbar al-hajar mā darab }
\end{aligned}
$$

\section{Literal translation}

The one who enlarged the stone (picked the larger stone) will not be able to hit.TheTT equivalent is:

A barking dog never bites (Oxford Concise Dictionary, 2003, p.13). Here, the literal translation of the proverb does not convey the meaning of the proverb to the TL audience. This proverb is used when a person threatens a lot, or promises to bring a mountain of gold, but his words are nonsense. The metaphor in the SL proverb is different from the metaphor in the TL equivalent.InToury'sterms of translating metaphor, the strategy that has been applied here is: metaphor in SL/ a replacementmetaphor in TL.

\section{Example 4:}

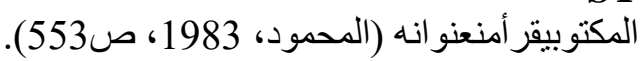

$$
\begin{aligned}
& \text { Al-maktūbyuqra' min 'inwānih }
\end{aligned}
$$

\section{Literal translation}

The letter is read by its title.

\section{TT nearest equivalent}

You cannot judge a book by its cover (White, 1987, p.151).

You can't tell a book by its cover (Oxford Concise Dictionary of Proverbs 2003, 35)

The translator can interfere to make it correspond to the positive case of the SLT. Therefore, an appropriate TT equivalent might be:

You can judge a book by its cover

Metaphor is kept in the ST and the TT.

So, in Toury's terms of translating metaphorthe strategy that has been applied here is: metaphor in SL/replaced metaphor in TL.

\section{Example 5:}

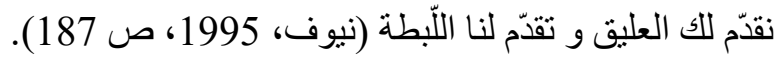

Literal translation

\section{Nuqaddimlaka al- ${ }^{c}$ alìqwatuqaddimlanā al-llabtah}

We offer you blackberry (fodder); while you offer us a kick.

The literal translation of this proverb does not convey the meaning of the proverb, unless the TL reader is aware of its cultural background fodder are usually given to farm animals as fodder. The words blackberry (fodder) and (kick) are metaphors for good deed and bad/evil reward,respectively. Therefore, the following paraphrase maylook clearer to the TT reader: we 
AWEJ for Translation \& Literary Studies volume, 1 Number 2, May 2017

Translating Figurative Proverbs from Two Syrian Novels

Issa

advise you and want the best for you and you kick everything and reward us with evil.Opting for this paraphrased translation of the ST indicates that the ST metaphor has not been preserved. This is in Toury's approach.Similarly, choosing the English equivalent: No good deed goes unpunished (Oxford Concise Dictionary of Proverbs 2003, 142), means the TT has not preserved the metaphor in the ST.

Example 6:

TT

$$
\begin{aligned}
& \text { ST } \\
& \text { الدّجاجه، اقطع منقار ها-لا نغيّر كار ها (نيوف، 1995، 181ata 181). } \\
& \text { Al-dajājah, iqțacminqārahālātuġayyerkārahā }
\end{aligned}
$$

Even if you cut off the hen's beak, it will never change its trade/habit.

Here, the literal translation of the proverb has kept the metaphor. However, the translation remains ambiguous for the TL reader, unless this reader is familiar with the cultural background of the proverb. A proper way to explicate this ambiguity is through explaining/ paraphrasing the proverb: "a man cannot easily desert his habit".

Another way to translate this proverb is finding its equivalent in the TL.

The best-known English equivalent is:

A leopard can't/doesn't change its spots

(http://dictionary.cambridge.org/dictionary/english/a-leopard-can-t).It is noticed here how the metaphor, represented in the impossibility of changing one's habit, has been kept in the English equivalent. However, the translator has,inToury's terms, replaced the SL metaphor with a TL different metaphor. .

\section{Example 7:}

$$
\begin{aligned}
& \text { الصتّابون كلّه عند البدو صابون (نيوف، 1995، 75 } \\
& \text { Al-șābūnkulluhcind al-badūṣābūn }
\end{aligned}
$$

\section{TT}

For the Bedouins, all soap is soap.

Here, the literal translation of the proverb has kept the metaphor. However, the translation is not clear for the TT reader, unless this reader is familiar with the cultural background of the proverb. A suitable translation could be produced through explaining/paraphrasing the proverb. It may become as follows: "Bedouins do not have any taste". But in this translation, the metaphor "soap" has been dropped. In Toury's terms, the translator has opted for finding a nonmetaphorical translation for the metaphorical SL text.

\section{Formal features of the proverbs}

Phonic features are typically found in most of the proverbs. Amongst these phonic features arealliteration and assonance. Trench (1854, p. 21), supports this view by perceiving that alliteration is an important aspect of proverbs. He (1854, p. 21), gives an example of a proverb with alliteration: "Who swims in sin, shall sink in sorrow". Other prominent scholars, Dickins, Hervey and Higgins (2002, p. 81) define alliteration as "the recurrence of the same sound or 
AWEJ for Translation \& Literary Studies volume, 1 Number 2, May 2017

Translating Figurative Proverbs from Two Syrian Novels

Issa

sound-cluster at the beginning of words, as in 'two tired toads"'. Dickinset al. (p. 81), go on to define assonance as: "the recurrence, within words, of the same sound or sound-cluster, as in 'a great day's painting"'.

\subsection{Examples of proverbs with alliteration and assonance}

This section will present four proverbs with the external markers of alliteration and assonance. The first two examples are taken from the Syrian novel Muftaraq al-MațarbyYusuf alMahmūd; while the last two examples are taken from the other Syrian novelAnäjīl alXarāb by NaufalNayouf.

Example 1:

TT

$$
\text { كانون، كن في بيتك، يا مجنون (المحمود، 1983، ص285). }
$$

Kānūn kin fïbeytakyāmajnūn

December/January, stay at home, you madman.

In the ST, there is assonance as the sound " $\bar{u}$ " is repeated in the two wordsنكانونkānūnandmajnūnنمنون.In the TT, this stylistic featurehas not been preserved.

\section{Example 2:}

TT

$$
\begin{aligned}
& \text { الجدي لا يظلّ جدياً، يصير له قرون ويناطح (المحمود، 1983، ص6464). } \\
& \text { Al-jadīlāyadallujadyan, yașīrulahuqurūnwayunāțị̣ }
\end{aligned}
$$

The goat does not remain a goat; it grows horns and fights.

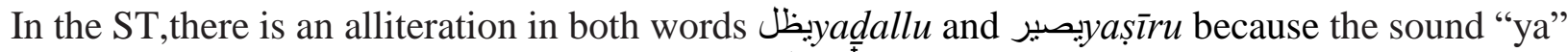

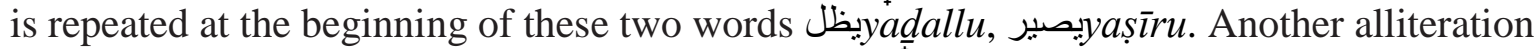
occurs in the two words $\vee l \bar{a}$ and $\sqcup l a h u$,where the sound "la" is repeated at the beginning of both words. In the TT, there is alliteration in the words "goat", "goat" and "grows". This means that thisphonicfeaturehas been preserved intheTT as well.

\section{Example 3:}

ST

$$
\text { قطع الأعناق و لا قطع الأرزاق (نيوف، ST }
$$$$
\text { qat }{ }^{c} \text { alànāqwalāqat }{ }^{c} \text { alarzāq. }
$$

TT

Cutting off someone's neck is better than preventing him earning his livelihood.

In the ST, there is assonance as the sound " $\overline{\mathrm{a}}$ " is repeated in the three words الأعناق

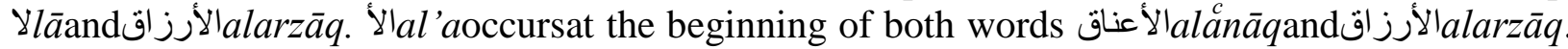
This is alliteration. In the TT, we notice there is rhyme in the words (cutting), (preventing) and (earning); while in the ST, there is rhyme only in the first two words: قطع qat (cutting) and قطع qat (preventing). There is also assonance in the three words as the sound (ing) is repeated.There is alsoalliteration in the TT in the words (his) and (him). So, the stylistic deviceshavebeenmostlykept.

Example 4:

ST 
AWEJ for Translation \& Literary Studies volume, 1 Number 2, May 2017

Translating Figurative Proverbs from Two Syrian Novels

Issa

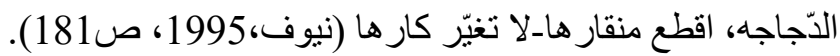

$$
\begin{aligned}
& \text { Al-dajājah, iqtạcminqārahālātuġayyerkāahahā }
\end{aligned}
$$

\section{TT}

Even if you cut off the hen's beak, it will never change its trade.

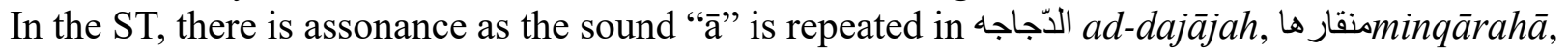

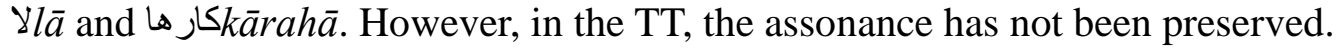

\subsection{Rhyme}

Rhyme is a poetic characteristic which is not confined to poetry only, but rather exists in proverbs as well. Dickins, Hervey and Higgins (2002, p. 81) define rhyme in English as follows: "We shall say that two words rhyme where the last stressed vowel, and all the sounds that follow it, are identical and occur in the same order, as in 'bream/seem"." Rhyme is also seen by Trench $(1854$, p. 20), asone of the majorcharacteristics of proverbs. Trench (ibid) gives the following examples about this stylistic device, "Who goes a borrowing, goes a sorrowing" and "Truth may be blamed, but cannot be shamed".

\subsubsection{Examples of proverbs with rhyme}

This section will present four proverbs with the rhyme stylistic device. The first

two examples are taken from the Syrian novel Muftaraqal-MatarbyYusufal-Mahmūd;while the last two examples are taken from the other Syrian novel,Anājīl al-Xarāb by NaufalNayouf.

\section{Example 1:}

$$
\begin{aligned}
& \text { اذكريالدّيبو هيّر يالقضيب (المحمود، 1983 ، ص4903) } \\
& \text { it tkrīaddībwahayyirīalqad̄īb }
\end{aligned}
$$

\section{TT}

Mention the wolf and prepare the stick.

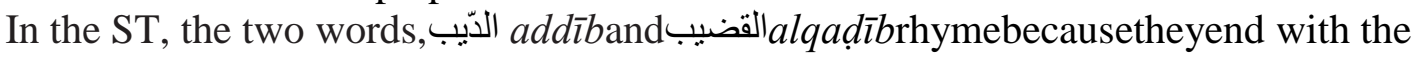
same vowel and consonant combination " īb". Another pair of words rhyme together: هيّرب hayyirī.TheTT equivalence is: Speak of the devil and he'll appear (Mieder, 1992,p.197).In the TT, there is no rhyme, but there is assonance in the words speak and appear.

Example 2:

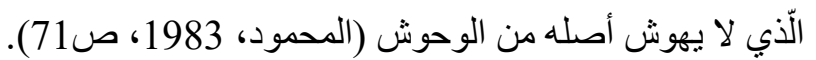

$$
\begin{aligned}
& \text { Al-latî̄lāyahūšs 'ạṣluhumin al-wuhūūš }
\end{aligned}
$$

TT

He who does not feel jealousy is a beast by origin.

Here in the ST, there is rhyme between يوشyahūš(feel jealousy)and وحوشwuḥūs(beasts) because there is correspondence of vowel and consonantal sounds in both words. This is represented in the repetition of the sequence " $h \bar{u} \breve{s}$ " at the end of each of both words. However, in the TT, the rhyme has not been kept. 


\section{Example 3:}

TT

$$
\begin{aligned}
& \text { الدّنيا بلا شر اب خر اب (نيوف، 1995، ص176 } \\
& \text { Al-dunyābalāšarābxarāb }
\end{aligned}
$$

Life without drink is a wreck.

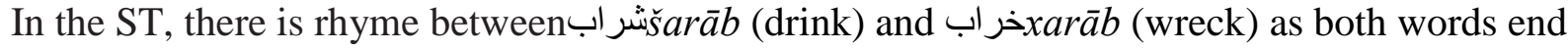
with the same sequence " $r \bar{a} b$ ". In the TT, there is no rhyme, but there is consonance in the words "drink" and "wreck".

\section{Example 4:}

$$
\begin{array}{r}
\text { ST } \\
\text { أنت نعمل من الحبّة قبّة (نيوف، 1995، ص851a tacmal min al-habba qubba }
\end{array}
$$

TT

But you make a dome-tomb out of a seed.

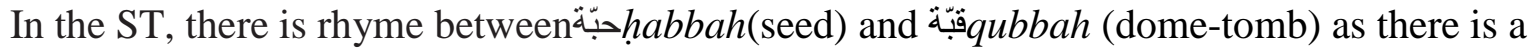
correspondence between the vowel and consonantal sounds "bbah" at the end of both words. However, in the TT, there is no rhyme.

\section{Conclusion}

When translating seven metaphorical proverbs from both novelsMuftaraq al-MațarbyYusuf alMahmmūd and Anājīl al-Xarāb by NaufalNayouf, it was noticed that in four examples the metaphor has been dropped or has disappeared in the TT. This meant in Toury's terms: ST metaphor/TT non-metaphor. However, in the other three SL metaphorical proverbs, the SL metaphor was replaced by the TL metaphor. In Toury'sterms, SL metaphor/TL different metaphor.Regarding the external stylistic features of the eight studied proverbs, we have seen that two out of four proverbs with alliteration and assonance have preserved the phonic features of the ST in the TT. However, in the other four examples, which focused on rhyme, it is obvious that rhyme in the ST has not been preserved in the TT. Overall, when translating figurative proverbs, it almost becomes too hard to preserve the ST figures of speech in the TT.

\section{About the Author:}

HuwaidaIssa is a visiting scholar at the University of Leeds. She got her $\mathrm{PhD}$ in Arabic Literature under the supervision of professor James Dickins at the University of Leeds in the UK. Her thesis researched proverbs, modified proverbs and curses in two Syrian novels. She got an MA in Literary Criticism, a Higher Diploma and a BA in English Language and Literature.

\section{References:}

Adééko, A.(1998). Proverbs, Textuality, and Nativism in African Literature. Gainesville: University Press of Florida.

Al- Timen, F. A. A. (2015). An Analysis of Translation Methods for English Proverbs: Literal, Literary or Substitution.European Academic Research II(11).Retrieved from http://www.academia.edu/10451042/An_Analysis_of_Translation_Methods_for_English_Prover bs [Accessed14December2016]. 
AWEJ for Translation \& Literary Studies volume, 1 Number 2, May 2017

Translating Figurative Proverbs from Two Syrian Novels

Issa

Al Salem, M. N.(2014). The Translation of Metaphor of Arabic to English in Selected Poems of Mahmoud Darwishwith Focus on Linguistic Issues (PhD).University of Leeds: Centre for Translation Studies.

Arora, S. L. (1984). The Perception of Proverbiality. Proverbium: Yearbook of International Proverb Scholarship 1, 1-38.

Baker, M. (1992).In Other Words: A Coursebook on Translation. London and New York: Routledge.

Balfakeeh, N. (2009). Strategies for Translating Idioms and Culturally-bound Expressions within the Human Development Genre(MA). University of Birmingham, Department of English: Centre for English Language Studies.

Bock',J. K.\& Brewer, W. F. (1980). Journal of Psycholinguistic Research. New York: Plenum Publishing Corporation. 9(I), 59-72.

Dabaghi, A., Pishbin, El. \&Niknasab, L. (2010). Proverbs from the Viewpoint of Translation. Journal of Language Teaching and Research. Finland: Academy Publisher,1(6), 807814.

Dickins, J., Hervey, S.G.J. \&Higgins. I.(2002). Thinking Arabic Translation. London and New York: Routledge.

Dickins, J. (2012). Procedures for Translating Culturally Specific Items. In A., Littlejohn \&RaoMehta,S. (eds.),Language Studies: Stretching the Boundaries. Newcastle upon Tyne: Cambridge Scholars Publishing.

Honeck, R. (1997). A Proverb in Mind: the Cognitive Science of Proverbial Wit and Wisdom. USA: Lawrence Erlbaum.

Jesenšek, V. (2014).Pragmatic and Stylistic Aspects of Proverbs. InH. HrisztovaGotthardt\&Varga, M. A. (eds.),Introduction to Paremiology: A Comprehensive Guide to Proverb Studies (pp.133-161). Berlin: Walter de Gruyter GmbH and Co KG.

Larson, M. L. (1984).Meaning-Based Translation: A Guide to Cross-Language Equivalence. Lanham and New York: University Press of America, Inc.

"A Leopard Cannot Change its Spots". Retrieved fromhttp://dictionary.cambridge.org/dictionary/english/a-leopard-can-t-doesn-t-changeits-spots

Longman III, T. (2002).How to Read Proverbs. Illinois: Inter-Varsity Press.

Mieder, W. (1985). "Popular Views of the Proverb." Proverbium 2, 109-143.

Mieder, W., S. A. Kingsbury, \&K. B. Harder(eds.), (1992). A Dictionary of American Proverbs. Oxford: Oxford University Press.

Meider, W. \&A. Dundes(eds.),(1995). The Wisdom of Many: Essays on the Proverb. NewYork: Garland.

Mieder, W. (2004). Proverbs: A Handbook. Westport: Greenwood Publishing Group.

Mieder, W. (2008). "Proverbs Speak Louder than Words": Folk Wisdom in Art, Culture, Folklore, History, Literature and Mass Media. New York: Peter Lang.

Munday, J. (2012).Introducing Translation Studies: Theories and Applications, ( $3^{\text {rd }}$ ed.). London and New York: Routledge.

Newmark, P. (1998).More Paragraphs on Translation. New Jersey University Press: Multilingual Matters.

Nord, C. (1997).Translating as a Purposeful Activity: Functionalist Approaches Explained. Manchester: St. Jerome Publishing. 
AWEJ for Translation \& Literary Studies volume, 1 Number 2, May 2017

Translating Figurative Proverbs from Two Syrian Novels

Issa

Norrick, N. (1985). How Proverbs Mean: Semantic Studies in English Proverbs. Berlin: De Gruyter Mouton.

No good deed goes unpunished.(2003). Oxford Concise Dictionary of Proverbs. Oxford: Oxford University Press.

Poucke, P. V.\&Belikova, A. (2016). Foreignization in News Translation: Metaphors in Russian Translation on the News Translation Website InoSMI.Meta: journal des traducteurs / Meta: Translators' Journal, 61(2), 346-368.

Sánchez, M. T. (2007). Translation and Sociolinguistics: Can Language Translate Society?Babel, 53(2), 123-131.

Sandoval, T. J. (2006). The Discourse of Wealth and Poverty in the Book of Proverbs. Leiden: Brill.

Toury, G. (1995). Descriptive Translation Studies and Beyond. Amsterdam/Philadelphia: John Benjamins.

Trench, R.C.(1854). Lessons in Proverbs: Being the Substance of Lectures Delivered to Young Men's Societies, ( $3^{\text {rd }}$ ed.). London: John W. Parker.

White, G. M.,(1987). Proverbs and Cultural Models: An American PsychologyofProblem Solving. In D. Holland\&N. Quinn (eds.),Cultural Models in Language and Thought. Cambridge (pp.151-172). UKand New York: Cambridge University Press.

Arabic Printed works

$$
\text { نميوف، نوف، أحمد يوسف (ال). 1983. مفترق المطر. ، دمشقى: اتحاد الكتّاب العرب. }
$$

